\title{
CORRELATIONS OF CADMIUM EXPOSURE WITH THE UREUM AND CREATININE SERUM LEVELS IN BATURADEN ORNAMENTAL PLANT FARMERS
}

\section{KORELASI PAPARAN KADMIUM TERHDAP KADAR UREUM DAN KREATININ SERUM PADA PETANI TANAMAN HIAS BATURRADEN}

\author{
Nafiisah Nafiisah', Agung Saprasetya Dwi Laksana², Joko Mulyanto \\ ${ }^{1}$ Histology Department, Faculty of Medicine Jenderal Soedirman University \\ ${ }^{2}$ Community Health and Environmental Medicine Departement, Faculty of Medicine Jenderal \\ Soedirman University \\ Corresponding Author: Nafiisah. Email: dr.nafiisah@unsoed.ac.id
}

\begin{abstract}
Baturaden ornamental plant farmers use pesticides and fertilizers containing cadmium to increase growth and plant diseases control. Cadmium is a very toxic heavy metal. Small doses of cadmium exposure in over a long time through respiratory tract, digestion, and skin penetration causes a workload on the kidneys. It resulting kidney damage that characterized by increased ureum and creatinine serum levels. The aimed of this study was determine the correlation of cadmium exposure to kidney function in terms of urea and creatinine serum levels. The research design was an observational analytic approach with cross sectional method. The respondents were 43 farmers. Research data were collected by interviews, measured the urea and creatinine serum levels, also the cadmium urine levels. Data were analyzed by Spearman test. The results showed that there was a weak significant correlation between cadmium urine to ureum $(r=0.399$ and $p=0.008)$ and creatinine serum levels $(r=0.331$ and $p=0.03)$. We concluded that cadmium exposured correlated with increased ureum and creatinine serum levels.
\end{abstract}

Keywords: Cadmium, Urea Serum Level, Creatinine Serum Level, Ornamental Plant Farmers

\section{ABSTRAK}

Petani tanaman hias di Baturaden menggunakan pestisida dan pupuk yang mengandung kadmium untuk meningkatkan pertumbuhan dan pengendalian penyakit tanaman. Kadmium adalah logam berat yang sangat beracun. Paparan kadmium dosis kecil dalam jangka waktu yang lama melalui saluran pernafasan, pencernaan, dan penetrasi kulit menyebabkan beban kerja pada ginjal. Hal tersebut mengakibatkan kerusakan ginjal yang ditandai dengan peningkatan kadar ureum dan kreatinin serum. Penelitian ini bertujuan untuk mengetahui hubungan paparan kadmium terhadap fungsi ginjal ditinjau dari kadar ureum dan kreatinin serum. Desain penelitian adalah observasional analitik dengan metode cross sectional. Respondennya sebanyak 43 petani. Pengumpulan data penelitian dilakukan dengan wawancara, pengukuran kadar urea dan kreatinin serum, serta kadar kadmium urin. Data dianalisis dengan uji Spearman. Hasil penelitian menunjukkan bahwa terdapat hubungan bermakna yang lemah antara kadar kadmium urin dengan kadar serum ureum $(r=0,399$ dan $p=0,008)$ dan kreatinin $(r=0,331$ dan $p=0,03)$. Kami menyimpulkan bahwa paparan kadmium berkorelasi dengan peningkatan kadar ureum dan kreatinin serum.

Kata Kunci: Kadmium, Kadar Ureum Serum, Kadar Kreatini Serum, Petani Tanaman Hias

How To Cite: Nafiisah, N., Laksana, A., \& Mulyanto, J. (2020). CORRELATIONS OF CADMIUM EXPOSURE WITH THE UREUM AND CREATININE SERUM LEVELS IN BATURADEN ORNAMENTAL PLANT FARMERS. Biomedika, 12(2), 79-84. doi:https://doi.org/10.23917/biomedika.v12i2.10416

DOI: https://doi.org/10.23917/ biomedika.v12i2.10416 


\section{INTRODUCTION}

Cadmium is a very toxic heavy metal and classified as a carcinogenic compound in humans (Agency for Toxic Substances and Disease Registry (ATSDR), 2008). In Indonesia, farmers use pesticides and fertilizers containing cadmium to increase growth and control pests and plant diseases. Cadmium levels in pesticides were found at $0.018 \mathrm{ppm}$ and $11 \mathrm{ppm}$ in fertilizer (Kusdiarti et al., 2014). Pesticides and fertilizers are often used excessively and continuously, causing adverse impacts on the environment and human health (Nopriani, 2011).

Cadmium enter the tissues of living things through the respiratory tract, digestive tract, and skin penetration. Cadmium that has entered the body, will be absorbed and blood transported to the liver and kidneys. It bind to Metallothionein (MT) in the blood (Kim et al., 2015). Small doses of cadmium exposure in over a long time cause kidney accumulation. It cause a workload on the kidneys, resulting kidney damage characterized by proteinuria, glycosuria, increased ureum and creatinine serum levels, as well as decreased Glomerular Filtration Rate (GFR) (Sudarmadji et al., 2006). Weaver et al. (2011) states that there is a significant relationship between increased levels of urine cadmium with increased ureum and creatinine serum levels in lead workers. Swaddiwudhipong et al. (2007) research showed a significant relationship between increased levels of cadmium with decreased kidney function in farmers.

Farmers, including Baturaden ornamental plant farmers, are one of the great risk groups of cadmium exposure derived from pesticides and phosphate fertilizers, but there is still little research related to the impact of cadmium exposure on the health of workers whose daily contact with cadmium in Indonesia such as ornamental plant farmers. This study was conducted to determine the correlation of cadmium exposure to the kidney function in terms of urea and creatinine serum levels in ornamental plant farmers.

\section{METHOD}

The research was conducted in January 2016. Blood and urine collection from ornamental plant farmers was carried out around Baturraden. Urea and creatinine serum tests were conducted using enzymatic kinetics methode at the Main Laboratory of Medico Labora Purwokerto and examination of cadmium urine levels was carried out using Atomic Absortion Sprectometry (AAS) at the Laboratory of 
Chemistry, Faculty of Mathematics and Natural

Sciences, Gajah Mada University, Yogyakarta.

This research design was an

observational analytic approach with cross sectional method. The respondents were 43 ornamental plant farmers in Baturaden. The inclusion criteria was respondents with a minimum working period of 1 year who were willing to sign informed consent. The exclusion criteria were respondents who had a history of diabetes mellitus and hypertension.

This research ethichal clearance got from the Ethics Commission of the Faculty of Medicine, Jenderal Soedirman University and obtained approval with No Ref. 001/KEPK/I/2016. Data on the measurement of the parameters of cadmium urine, ureum and creatinine serum levels were analyzed with Spearman test.

\section{RESULT AND DISCUSSION}

\section{Cadmium Urine Levels}

The frequency distribution of cadmium urine $(\mu \mathrm{g} / \mathrm{L})$ in respondents can be seen in table 1.

Table 1. Frequency Distribution of Urine Cadmium $(\mu \mathrm{g} / \mathrm{L})$ in Respondents

\begin{tabular}{lc}
\multicolumn{2}{c}{ Cadmium $(\boldsymbol{\mu g} / \mathbf{L})$ in Respondents } \\
\hline$N$ & Cadmium Levels \\
\hline Mean & 43 \\
Median & 5,34 \\
\hline
\end{tabular}

\begin{tabular}{lc}
\hline Mode & 5,00 \\
Minimum Value & 5,00 \\
Maximum Value & 10,00 \\
Standard Deviation & 0,12 \\
\hline
\end{tabular}

From table 1 it is shown that the average cadmium level in all respondents is above the normal threshold, which is above $2 \mu \mathrm{g} / \mathrm{L}$. This shows that all respondents experienced high levels of cadmium exposure.

The process of using pesticides and fertilizers containing cadmium causes these substances to enter the body of ornamental plant farmers through the respiratory tract, digestive tract, and skin penetration. Cadmium that enters the body through the respiratory tract is caused by cadmium-contaminated work environment air pollution (Palar, 2008).

The amount of cadmium in the body can be influenced by several things, such as: age, smoking habits, sex and diet (Adnan et al., 2012; Malgorzata et al., 2008; Mortensen et al., 2011; Menke, 2009).

\section{Ureum and Creatinine Serum levels}

The frequency distribution and correlation cadmium exposure to respondents ureum-creatinine serum levels can be seen in table 2 . The average of ureum and creatine serum levels respondents were $25.79 \mathrm{mg} / \mathrm{dL}$ and 1.17 $\mathrm{mg} / \mathrm{dL}$ (within normal limits). The mean, median 
and mode values indicate urea and creatinine serum levels were still within normal limits too.

This means that the majority of respondents have normal urea and creatinine serum levels.

Table 2. Frequency Distribution and Correlation Cadmium Exposure to Respondents UreumCreatinine Serum Levels

\begin{tabular}{lcc}
\hline & $\begin{array}{l}\text { Ureum } \\
\text { Levels } \\
(\mathbf{m g} / \mathbf{L})\end{array}$ & $\begin{array}{l}\text { Creatinine } \\
\text { Levels } \\
(\mathbf{m g} / \mathbf{L})\end{array}$ \\
\hline $\mathrm{N}$ & 43 & 43 \\
Mean & 25.79 & 1.17 \\
Median & 19.00 & 1.16 \\
Mode & 21.00 & 1.18 \\
Value & 16.00 & 0.97 \\
Value & 53.00 & 1.58 \\
Standard Deviation & 10.78 & 0.15 \\
$p$ value & 0.008 & 0.03 \\
$\mathrm{r}$ (correlation power) & 0.399 & 0.331 \\
\hline
\end{tabular}

Heavy metal poisoning cause an increased of urea and creatinine serum levels (Sugiharto et al., 2016). In addition, the other things that affect urea and creatinine serum levels in the human body are: fluid factors, protein and carbohydrate diets and the use of drugs (National Kidney Foundation, 2009; Hidayati et al., 2008).

The results of the analysis with the Spearman correlation test showed there was a weak significant correlation between cadmium urine levels with ureum $(r=0.399$ and $p=0.008)$ and creatinine serum levels $(\mathrm{r}=0.331$ and $\mathrm{p}=$ 0.03). A positive $r$ value indicates that the higher of cadmium urine level made the higher of ureum and creatinine serum levels. This studies result was consistent with Weaver et al. (2011) research that showed a significant relationship between increased of cadmium urine levels with increased ureum and creatinine serum levels. Research conducted by Kim et al. (2015) also mentioned that the decrease in GFR and the increase in creatinine can be caused by continuously cadmium exposure.

Continuous cadmium exposure cause kidney function decreased. Cadmium that enters the body will mostly accumulate in the liver and kidneys. Cadmium that has entered the body be distributed through blood circulation and reach the liver. Furthermore, cadmium in the liver will bind to the protein Metalothionin (MT) to form the Cd-MT complex which produce $\mathrm{Cd} 2+$ which is toxic (Bernard, 2008). After passing through the liver, the Cd-MT complex will re-circulate in the blood circulation and end up in several tissues and human organs, one of which is the kidney. The presence of cadmium in the body inhibit the work of various enzymes, including the Superoxide Dismutase (SOD) enzymes, catalase (CAT) enzymes, Glutathione Peroxidase (GPx) enzymes, Glutathione S-Transferase (GST) enzymes and dehydroginase enzymes. These enzymes inhibition cause the kidney's cadmium 
accumulation. The long half-life of cadmium, the low excretion rate, and the excretion of cadmium which usually starts at the age of 50 increase the amount of cadmium accumulation. Furthermore, the cadmium accumulation be excreted in the urine resulting the increased of cadmium urine levels (Houston, 2007).

Most cadmium destroys nephrons. Nephron damage occurs because the cadmium is released into the tubules lumen and causes the renal tubular protein membrane damaged (Johri et al., 2010). This damaged cause the kidney's ability to filter and reabsorb various substances lost. Albumin excretes to the urine and toxic substances such as ureum and creatinine accumulates in the body (Kim et al., 2015).

\section{CONCLUSION AND SUGGESTION}

Cadmium exposure is associated with decreased kidney function in ornamental plant farmers characterized by increased levels of ureum and creatinine serum levels.

Suggestions that can be given for ornamental plant farmers is to use personal protective equipments such as masks, gloves and boots when working to avoid exposure to pesticides and fertilizers containing cadmium. Ornamental plant farmers are also advised to consume healthy foods such as fruits, especially those containing high vitamin $\mathrm{C}$ because it contains high antioxidants.

\section{REFERENCES}

Adnan, J.A., Shah, S.A., Jaafar, M.H., and Jadoo, S.A. 2012. Urinary Cadmium Concentration and its Risk Factors among Adults in Tanjung Karang, Selangor. AmericanEurasian Journal of Toxicological Sciences. 4(2). Pp: $80-8$.

Agency for Toxic Substances and Disease Registry (ATSDR). 2008. Cadmium Toxicity. Georgia: Agency for Toxic Substances and Disease Registry.

Bernard, A. 2008. Cadmium \& its adverse effects on human health. Indian Journal of Medical Research. 128. Pp: $557-64$.

Hidayati, T., Kushadiwijaya, H., and Suhadi. 2009. Hubungan Antara Hipertensi, Merokok, dan Minuman Suplemen energi dan Kejadian Penyakit Ginjal Kronik. Berita Kedokteran Masyarakat. 24(2). Pp: 90-102.

Houston. 2007. The Role of Mercury and Cadmium Heavy Metals in Vascular Disease, Hypertension, Coronary Heart Disease, and Myocardial infraction. Proquest Nursing \& Allied Health Source. 13(2).

Johri, N., Gregory, J., and Robert, U. 2010. Heavy Metal Poisoning The Effects of Cadmium on The Kidney. Biometals. 23. Pp: 783-92.

Kim, N.H., Hyun, Y.Y., Lee, K.B., Chang, Y., Rhu, S., Oh, K.H., and Ahn, C. 2015 Environmental heavy metal exposure and chronic kidney disease in the general population. J.Korean Med. Sci. 30. Pp: 2727.

Malgorzata, G.D., Malgorzata, M.B., and Janina, M.J. 2008. Estimation of Polish Cigarettes Contamination with Cadmium and Lead and Exposure to These Metals via Smoking. Environmental Monitoring and Assessment. 137. Pp: 481-93.

Menke, A., Muntner, P., Silbergeld, E.K., Platz, E.A., and Guallar, E. 2009. Cadmium Levels 
in Urine and Mortality among U.S. Adults. Environmental Health Perspectives. 117(2). Pp: 190 - 196.

Mortensen, M.E., Wong, L.Y., and Osterloh, J.D. 2011. Smoking Status and Urine Cadmium above Levels Associated with Subclinical Renal Effects in U.S Adults Without Chronic Kidney Disease. Environmental Health. 214. Pp: 305-10.

National Kidney Foundation. 2009. Chronic Kidney Disease. New York: National Kidney Foundation.

Nopriani, L.S. 2011. Teknik Uji Cepat Untuk Identifikasi Pencemaran Logam Berat Tanah di Lahan Apel Batu. Disertasi. Fakultas Pertanian. Universitas Brawijaya, Malang.

Palar, H. 2008. Pencemaran dan Toksikologi Logam Berat. Jakarta: Penerbit Rineka Cipta.

Sudarmadji, Mukono J., dan Corie, I. P. 2006. Toksikologi Logam Berat B3 dan
Dampaknya Terhadap Kesehatan. Jurnal Kesehatan Lingkungan. 2(2). Pp: 129-42.

Sugiharto, S.B., Suwarso, S., dan Prawirohardjono, W. 2016. Level Kadmium Darah dan Fungsi Ginjal Ditinjau dari Kadar Ureum dan Kreatinin Pekerja Las Bengkel Knalpot di Purbalingga. Berita Kedokteran Masyarakat. 32(4). Pp:119-24.

Swaddiwudhipong, W., Limpatanachote, P., Mahasakpan, P, Krintratun, S. and Padungtod, C. 2007. Cadmium-exposed population in Mae Sot District, Tak Province: 1. Prevalence of high urinary cadmium levels in the adults. J.Med. Assoc. 90. Pp: 143-148.

Weaver, V.M., Kim, N.S., Jaar, B.G., Schwartz, B. S., Parsons, P. J., Steuerwald, A. J., Todd, A.C., Simon, D., and Lee, B.K. 2011. Associations of low-level urine cadmium with kidney function in lead workers. Environmental Research. 68(4). Pp: 250 - 6. 